\title{
Embodied Carbon Emissions of Office Building: A Case Study of China's 78 Office Buildings
}

\author{
Zhixing Luo ${ }^{\text {a }}$, Liu Yang ${ }^{\text {a, }}$, Jiaping Liu ${ }^{\text {a }}$

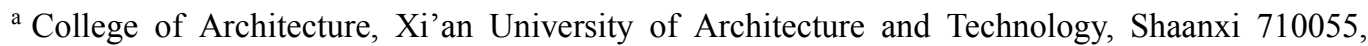 \\ China \\ * Corresponding author. Tel.: +86 029 82205390; fax: +86 029 82205390. E-mail address: \\ yangliu@xauat.edu.cn (YANG Liu).
}

Abstract: $\mathrm{A} \mathrm{CO}_{2}$ emission in construction materialization stage is the key research point of architectural life cycle assessment, which is concentrated in emission time and in absolute emission volume. To build a calculation model for $\mathrm{CO}_{2}$ emissions in the materialization stage of office buildings, it should take into consideration the $\mathrm{CO}_{2}$ emissions generated from production and transportation of construction materials and equipment as well as the $\mathrm{CO}_{2}$ emissions generated from the construction process. By this calculation model, the $\mathrm{CO}_{2}$ emissions are analyzed and calculated of 78 office buildings in construction materialization stage. On average, the $\mathrm{CO}_{2}$ emissions in construction materialization stage are $326.75 \mathrm{~kg}-\mathrm{CO}_{2} / \mathrm{m}^{2}$; with the increase of building height, $\mathrm{CO}_{2}$ emissions per unit area increase significantly and the $\mathrm{CO}_{2}$ emissions per unit area of super-high-rise buildings are 1.5 times that of the multi-storey buildings; the $\mathrm{CO}_{2}$ emissions of Civil Engineering account for $75 \%$ of the whole construction materialization stage; And the carbon emissions of steel, concrete, mortar and wall materials reach over $80 \%$ of the Civil Engineering. The storeys of the building and the consumption of construction materials are taken as two independent variables to set up a prediction model for $\mathrm{CO}_{2}$ emissions of office buildings in materialization stage. By statistical analysis and comparison, it can be found that the prediction formula using steel reinforcement, concrete and wall materials as independent variables can better predicate $\mathrm{CO}_{2}$ emissions in the construction materialization stage.

Keywords: $\mathrm{CO}_{2}$ emission, life cycle assessment, materialization, office building 


\section{Introduction}

The impact of human activity on the climate has been regarded as a huge threat to the earth [1]. Against such background, it has become a major concern of the world, particularly of China to save energy and reduce greenhouse gas (GHG) emissions represented by $\mathrm{CO}_{2}$ [2]. Globally, the construction industry consumes about 30\% 40\% energy while producing $40 \% \sim 50 \%$ GHGs [3]. Thus, it is not only a top environmental issue for construction industry but also a must-taken international responsibility to study how construction industry should reduce GHG emissions [4]. It is generally agreed that our climates are changing and that the average temperature will rise gradually. In response to this, there have been a number of researches on the impact of climate change on energy consumption and carbon emissions of office buildings in China [5-7], Sweden[8], Greece[9], and Australia[10].

The life cycle of a building includes the materialization stage, the operation stage and the disposal stage [11]. The materialization stage comprises the production of construction materials, the processing and manufacturing of components, the field construction and installation required for the formation of engineering entity prior to the building being put into use [11]. The $\mathrm{CO}_{2}$ emissions in construction materialization stage include (1) underlying $\mathrm{CO}_{2}$ emissions generated from the production, manufacture and transport of construction materials (such as building pipelines and equipment, etc.) [12-13]; (2) direct carbon emissions generated from the use of energy during building construction [14-18]. Previous studies have attempted to investigate primary energy use for the preparation of building materials and to establish a $\mathrm{CO}_{2}$ emission inventory [19-21], which are considered to be preconditions for the analysis of building carbon emissions. In general, the evaluation of $\mathrm{CO}_{2}$ emissions of the materialization stage has become increasingly common in recent years. For example, Onat et al. [22] calculated $\mathrm{CO}_{2}$ emissions of the materialization stage for the benchmark year 2002 by using a comprehensive hybrid economic input-output life cycle analysis. Wan Omar et al. [23] derived hybrid embodied with energy and carbon emission intensities for reference cases in Australia and Malaysia, with the results compared with the previous hybrid models to identify key parameters and issues.

Researches at home and from abroad show that the $\mathrm{CO}_{2}$ emissions in construction 
materialization stage make up $5 \% \sim 20 \%$ of that of the architectural life cycle (the building life is taken as 50 years) [24-30]. Although the proportion is relatively small, the absolute volume of emissions are quite considerable because our country has a large amount of construction, and the $\mathrm{CO}_{2}$ emissions in materialization stage are mainly concentrated in construction period of $1 \sim 2$ years [31]. From a macro perspective, the building industry uses $40 \% \sim 50 \%$ national resources and consumes $30 \%$ of the total societal energy [32]. The underlying carbon emissions of the building industry account for $26.47 \%$ of that of all social sectors [33]. As a very common public building, office building has a greater impact on energy and environment and is a big consumer of energy and resource. Thus, it is representative to do a quantitative research of $\mathrm{CO}_{2}$ emissions of office buildings in materialization stage.

By the process-based LCI method, this paper sets up a calculation model for $\mathrm{CO}_{2}$ emissions of office buildings in materialization stage, taking into consideration the $\mathrm{CO}_{2}$ emissions generated from the production, transport and construction of construction materials and equipment. 78 office buildings are collected as samples, the $\mathrm{CO}_{2}$ emissions of each sample in materialization stage are calculated, and the proportion constitution of $\mathrm{CO}_{2}$ emissions in materialization stage are analyzed. On this basis, the $\mathrm{CO}_{2}$ emissions of office buildings in materialization stage can be predicted according to the statistical data.

\section{Methods}

\subsection{Case Description}

For more accurate, with the detailed and comprehensive understanding of the characteristics of $\mathrm{CO}_{2}$ emissions of China's office buildings in materialization stage, this study collected large amounts of engineering quantity data of office building construction. After screening, 78 office buildings were chosen as study samples (all being reinforced concrete structures), of which 19 are multi-story buildings (below $24 \mathrm{~m}), 44$ are high-rise buildings $(24 \mathrm{~m} \sim 100 \mathrm{~m})$ and 15 are super high-rise buildings (above 100m).

\subsection{Functional Unit}

Functional unit refers to the quantified product system performance as the base unit [34]. The 
basis role of functional unit is to provide reference for relevant inputs and outputs so as to ensure the comparability of LCA results. The definition of functional unit follows two basic principles: 1) functional unit must be measurable; 2) a system may have several functions simultaneously and what function should be chosen depends on the purpose and scope of the study [35].

As the buildings are different in size, the consumption of materials and machines varies differently, which would directly result in the great difference in $\mathrm{CO}_{2}$ emissions. Therefore, it lacks comparability to merely list the total carbon emissions of the buildings and evaluation indicators need to be established of horizontal comparability. It can effectively eliminate the effects caused by the difference in building size and other factors by using $\mathrm{CO}_{2}$ emissions per unit construction area as an indicator to evaluate $\mathrm{CO}_{2}$ emissions of office buildings in materialization, ensuring consistency and comparability among the results. Thus, $\mathrm{LCCO}_{2 \mathrm{M}}\left(\mathrm{kg}-\mathrm{CO}_{2} / \mathrm{m}^{2}\right), \mathrm{CO}_{2}$ emissions per unit construction area, can be taken as the functional unit of $\mathrm{CO}_{2}$ emissions of office buildings in materialization stage.

\subsection{Analysis Model}

In the materialization stage of office buildings, there are two main sources of $\mathrm{CO}_{2}$ emissions, that is, (1)the underlying carbon emissions generated from the production and transport of construction materials and the production of construction equipment; (2) the direct carbon emissions resulted from fossil fuels and electricity during the transport of construction materials and equipment, the construction process and the decoration process. Thus, the calculation model of $\mathrm{CO}_{2}$ emissions in construction materialization stage is as follow:

$$
\mathrm{TLCCO}_{2 M}=\mathrm{TLCCO}_{2 m a}+\mathrm{TLCCO}_{2 t r}+\mathrm{TLCCO}_{2 c o}
$$

where $\mathrm{TLCCO}_{2 \mathrm{M}}\left(\mathrm{kg}-\mathrm{CO}_{2}\right)$ represents the $\mathrm{CO}_{2}$ emissions in the materialization stage of office buildings, $\mathrm{TLCCO}_{2 \mathrm{ma}}\left(\mathrm{kg}-\mathrm{CO}_{2}\right)$ represents the $\mathrm{CO}_{2}$ emissions generated from the production of construction materials and equipment of office buildings, $T L C \mathrm{CO}_{2 \mathrm{rr}}\left(\mathrm{kg}-\mathrm{CO}_{2}\right)$ represents the $\mathrm{CO}_{2}$ emissions generated from the transport of construction materials and equipment of office buildings, and $\mathrm{TLCCO}_{2 \mathrm{co}}\left(\mathrm{kg}-\mathrm{CO}_{2}\right)$ represents the $\mathrm{CO}_{2}$ emissions generated from the construction of office buildings.

To be more specific, 


$$
\mathrm{TLCCO}_{2 m a}=\sum_{i=1}^{n}\left(Q_{i} \times N_{i}\right)
$$

where $\mathrm{Q}_{\mathrm{i}}\left(\mathrm{kg}-\mathrm{CO}_{2}\right)$ refers to the $\mathrm{CO}_{2}$ emissions generated from the production of some construction material, such as civil work, electric, water supply and drainage, decoration materials and HVAC (heating ventilation and air conditioning) equipment, etc; $\mathrm{N}_{\mathrm{i}} \mathrm{kg} / \mathrm{m}^{2} / \mathrm{m}^{3}$ ) refers to the quantity of some construction material.

$$
\mathrm{TLCCO}_{2 t r}=\sum_{i=1}^{n}\left(T_{i} \times M_{i} \times L_{i}\right)
$$

where, $\mathrm{T}_{\mathrm{i}}\left(\mathrm{kg}-\mathrm{CO}_{2} / \mathrm{t} \cdot \mathrm{km}\right)$ refers to the $\mathrm{CO}_{2}$ emissions generated by some transportation mode per unit distance-and-weight, $M_{i}(t)$ refers to the gross weight of some construction material, $\mathrm{L}_{\mathrm{i}}(\mathrm{km})$ refers to the transportation distance of some construction material.

$$
\operatorname{TLCCO}_{2 c o}=\sum_{j=1}^{m}\left|\sum_{i=1}^{n}\left(Q_{P j, i} \times M_{j, i}\right)\right|
$$

where, $\mathrm{Q}_{\mathrm{p}, \mathrm{i}}\left(\mathrm{kg}-\mathrm{CO}_{2}\right)$ refers to the $\mathrm{CO}_{2}$ emissions generated from the processing of the $\mathrm{i}$ construction material in the $\mathrm{j}$ construction process of the office building, $\mathrm{M}_{\mathrm{j}, \mathrm{i}}\left(\mathrm{kg} / \mathrm{m}^{2} / \mathrm{m}^{3}\right)$ refers to the quantity of the processed $i$ construction material in the $\mathrm{j}$ construction process of the office building.

The calculation model of the function unit in the construction materialization stage:

$$
\mathrm{LCCO}_{2 M}=\frac{\mathrm{TLCCO}_{2 M}}{A}
$$

where, $\mathrm{A}\left(\mathrm{m}^{2}\right)$ refers to the total construction area of the building.

For some designated office buildings, the smaller the $\mathrm{LCCO}_{2 \mathrm{M}}$ is, the smaller the $\mathrm{CO}_{2}$ emissions per unit construction area are, thus causing little influence on the environment.

\section{$2.4 \mathrm{CO}_{2}$ Emission Inventory Analysis of Constriction Materials}

This study detailed the $\mathrm{CO}_{2}$ emissions of each section in materialization stage of each sample. The author's related research results are used for the $\mathrm{CO}_{2}$ emission data of construction materials

\begin{tabular}{|c|c|c|c|c|c|c|c|}
\hline Material & Sand & Gravel & Steel & Cement & concrete & Perforated & Aerated \\
\hline
\end{tabular}
of civil work and transport. [15][36] (see Table 1). The $\mathrm{CO}_{2}$ emission data of construction materials covered by installation and decoration projects is taken from Taiwan's database [37].

Table $1 \mathrm{CO}_{2}$ emission data of partial materials of Civil Engineering 


\begin{tabular}{cccccccc}
\hline type & & & & & & clay brick & $\begin{array}{c}\text { concrete } \\
\text { block }\end{array}$ \\
\hline Unit & $\mathrm{kg} / \mathrm{m}^{3}$ & $\mathrm{~kg} / \mathrm{m}^{3}$ & $\mathrm{~kg} / \mathrm{t}$ & $\mathrm{kg} / \mathrm{t}$ & $\mathrm{kg} / \mathrm{m}^{3}$ & $\mathrm{~kg} /$ piece & $\mathrm{kg} /$ piece \\
$\begin{array}{c}\mathrm{CO}_{2} \\
\text { emissions }\end{array}$ & 3.19 & 4.00 & 894.75 & 685.74 & 301.97 & 0.75 & 1.18 \\
\hline
\end{tabular}

\section{Results}

\subsection{Analysis of CO2 Emissions of Each Itemized Project}

The construction process of buildings mainly include the Civil Engineering, installation project and decoration project, among which installation project consists of Water Supply and Sewage Engineering, electrical engineering, and HVAC engineering, etc.

Table 2 shows the $\mathrm{CO}_{2}$ emissions per unit area of each itemized project of buildings of different heights and the percentage they make up of all the projects. It can be found that the $\mathrm{CO}_{2}$ emissions per unit area of each itemized project increase with the height of the building. In general, the $\mathrm{CO}_{2}$ emissions of Super high-rise office buildings are 1.5 times that of multi-storey office buildings, and 1.3 times that of high-rise office buildings. That is because with the increase of the building height, $\mathrm{CO}_{2}$ emissions of Civil Engineering greatly increase while Civil Engineering is the main section in the entire building formation stage, making up an average of $75 \%$; meanwhile, with the increase of the building height, installation project and construction project also increase in the number and difficulty and the $\mathrm{CO}_{2}$ emissions of these sections also see a significant increase. Moreover, it can be found that there are few changes in $\mathrm{CO}_{2}$ emissions of installation project and the percentage it makes up, indicating that there is little relationship between $\mathrm{CO}_{2}$ emissions of installation project and the building height.

Table $2 \mathrm{CO}_{2}$ emissions per unit area of each itemized project and the proportion they make up

\begin{tabular}{cccccccccc}
\hline & Multi-story buildings & \multicolumn{2}{c}{ High-rise buildings } & \multicolumn{2}{c}{$\begin{array}{c}\text { Super high-rise } \\
\text { buildings }\end{array}$} & \multicolumn{2}{c}{ Weighted average } \\
\cline { 2 - 9 } & $\begin{array}{c}\mathrm{CO}_{2} \\
\text { Emissio } \\
\text { ns per } \\
\text { unit area } \\
\left(\mathrm{kg} / \mathrm{m}^{2}\right)\end{array}$ & $\begin{array}{c}\text { Percent } \\
\text { age } \\
(\%)\end{array}$ & $\begin{array}{c}\mathrm{CO}_{2} \\
\text { Emissio } \\
\text { ns per } \\
\text { unit area } \\
\left(\mathrm{kg} / \mathrm{m}^{2}\right)\end{array}$ & $\begin{array}{c}\text { Percent } \\
\text { age } \\
(\%)\end{array}$ & $\begin{array}{c}\mathrm{CO}_{2} \\
\text { Emissio } \\
\text { ns per } \\
\text { unit area } \\
\left(\mathrm{kg} / \mathrm{m}^{2}\right)\end{array}$ & $\begin{array}{c}\text { Percent } \\
\text { age } \\
(\%)\end{array}$ & $\begin{array}{c}\mathrm{CO}_{2} \\
\text { Emissio } \\
\text { ns per } \\
\text { unit area } \\
\left(\mathrm{kg} / \mathrm{m}^{2}\right)\end{array}$ & $\begin{array}{c}\text { Percent } \\
\text { age } \\
(\%)\end{array}$ \\
\hline $\begin{array}{c}\text { Civil } \\
\text { Engineering }\end{array}$ & 215.93 & 79.39 & 239.25 & 78.04 & 280.51 & 69.83 & 241.50 & 76.32 \\
Water Supply & 2.02 & 0.74 & 2.59 & 0.85 & 7.45 & 1.85 & 3.39 & 1.07
\end{tabular}




\begin{tabular}{|c|c|c|c|c|c|c|c|c|}
\hline & \multicolumn{2}{|c|}{ Multi-story buildings } & \multicolumn{2}{|c|}{ High-rise buildings } & \multicolumn{2}{|c|}{$\begin{array}{c}\text { Super high-rise } \\
\text { buildings }\end{array}$} & \multicolumn{2}{|c|}{ Weighted average } \\
\hline & $\begin{array}{c}\mathrm{CO}_{2} \\
\text { Emissio } \\
\text { ns per } \\
\text { unit area } \\
\left(\mathrm{kg} / \mathrm{m}^{2}\right) \\
\end{array}$ & $\begin{array}{l}\text { Percent } \\
\text { age } \\
(\%)\end{array}$ & $\begin{array}{c}\mathrm{CO}_{2} \\
\text { Emissio } \\
\text { ns per } \\
\text { unit area } \\
\left(\mathrm{kg} / \mathrm{m}^{2}\right) \\
\end{array}$ & $\begin{array}{l}\text { Percent } \\
\text { age } \\
(\%)\end{array}$ & $\begin{array}{c}\mathrm{CO}_{2} \\
\text { Emissio } \\
\text { ns per } \\
\text { unit area } \\
\left(\mathrm{kg} / \mathrm{m}^{2}\right) \\
\end{array}$ & $\begin{array}{l}\text { Percent } \\
\text { age } \\
(\%)\end{array}$ & $\begin{array}{c}\mathrm{CO}_{2} \\
\text { Emissio } \\
\text { ns per } \\
\text { unit area } \\
\left(\mathrm{kg} / \mathrm{m}^{2}\right) \\
\end{array}$ & $\begin{array}{c}\text { Percent } \\
\text { age } \\
(\%)\end{array}$ \\
\hline \multicolumn{9}{|l|}{ and Sewage } \\
\hline Engineering & & & & & & & & \\
\hline $\begin{array}{c}\text { Electrical } \\
\text { Engineering }\end{array}$ & 2.22 & 0.82 & 3.45 & 1.13 & 9.99 & 2.49 & 4.41 & 1.39 \\
\hline $\begin{array}{c}\text { HVAC } \\
\text { Engineering }\end{array}$ & 4.35 & 1.60 & 6.82 & 2.22 & 21.47 & 5.34 & 9.04 & 2.86 \\
\hline $\begin{array}{l}\text { Decoration } \\
\text { Engineering }\end{array}$ & 28.93 & 10.63 & 30.15 & 9.83 & 36.62 & 9.12 & 31.10 & 9.83 \\
\hline $\begin{array}{l}\text { Building } \\
\text { Construction }\end{array}$ & 18.54 & 6.82 & 24.3 & 7.93 & 45.66 & 11.37 & 27.00 & 8.53 \\
\hline Total & 271.99 & 100 & 306.56 & 100 & 401.70 & 100 & 316.44 & 100 \\
\hline
\end{tabular}

\subsection{Analysis of $\mathrm{CO}_{2}$ Emissions of Construction materials of Civil Engineering}

It can be seen from the above analysis that the $\mathrm{CO}_{2}$ emissions of Civil Engineering accounts for $76.32 \%$ that of the entire building formation stage. Thus, this section needs to be focused on.

\subsubsection{Analysis of $\mathrm{CO}_{2}$ emissions of Construction materials}

Table 3 shows the consumption and $\mathrm{CO}_{2}$ emissions of construction materials of Civil Engineering. We can find the followings: the higher the building is, the higher the consumption of steel and concrete. The steel consumption per unit area of super high-rise office building is $40 \%$ greater than that of multi-storey building, and the concrete consumption $60 \%$ greater. Higher building requires higher structural strength and it will increase steel consumption because steel is the major structural material of reinforced concrete structure; with the increase of building height, the cross-sectional area of architectural beam and column rises dramatically and the concrete consumption will increase because concrete is a compressive material of building structure. Steel reinforcement and concrete are the major construction materials of reinforced concrete building, and when they are calculated in $\mathrm{CO}_{2}$ emissions, it can be found that $\mathrm{CO}_{2}$ emissions of steel reinforcement and concrete of high-rise buildings are 1.2 times that of multi-storey buildings while $\mathrm{CO}_{2}$ emissions of super high-rise buildings are 1.5 times that of multi-storey buildings.

By analyzing the mean values, it can be found that the $\mathrm{CO}_{2}$ emissions are generated from the 
four types of construction materials such as steel, concrete, mortar and wall materials, etc. account for nearly $90 \%$ that of the entire Civil Engineering. However, when comparing the total $\mathrm{CO}_{2}$ emissions generated from the four types of construction materials among buildings of different heights, one can find little difference: the total $\mathrm{CO}_{2}$ emission of high-rise building is 1.1 times that of multi-storey while the total $\mathrm{CO}_{2}$ emission of super high-rise building is 1.25 times that of multi-storey. This is mainly because with the increase of the building height, the consumption of the mortar and wall material is gradually declining while the consumption of steel and concrete is just the opposite. The decline in the consumption of the mortar and wall material is caused by facade modeling and self-weight reduction required by super high-rise buildings and high-rise buildings. And more light materials as reflection glass curtain-wall are used, making the ratio of the window to the wall much bigger.

Table 3 Analysis of the consumption and $\mathrm{CO}_{2}$ emissions of construction materials

\begin{tabular}{ccccccccc}
\hline & \multicolumn{2}{c}{$\begin{array}{c}\text { Multi-story } \\
\text { buildings }\end{array}$} & \multicolumn{2}{c}{ High-rise buildings } & \multicolumn{2}{c}{$\begin{array}{c}\text { Super high-rise } \\
\text { buildings }\end{array}$} & \multicolumn{2}{c}{ Weighted average } \\
\cline { 2 - 9 } & $\begin{array}{c}\text { Material } \\
\text { consum } \\
\text { ption }\end{array}$ & $\begin{array}{c}\mathrm{CO}_{2} \\
\text { Emissio } \\
\mathrm{ns} \\
\left(\mathrm{kg} / \mathrm{m}^{2}\right)\end{array}$ & $\begin{array}{c}\text { Material } \\
\text { consum } \\
\text { ption }\end{array}$ & $\begin{array}{c}\mathrm{CO}_{2} \\
\text { Emissio } \\
\mathrm{ns} \\
\left(\mathrm{kg} / \mathrm{m}^{2}\right)\end{array}$ & $\begin{array}{c}\text { Material } \\
\text { consum } \\
\text { ption }\end{array}$ & $\begin{array}{c}\mathrm{CO}_{2} \\
\text { Emissio } \\
\mathrm{ns} \\
\left(\mathrm{kg} / \mathrm{m}^{2}\right)\end{array}$ & $\begin{array}{c}\text { Material } \\
\text { consum } \\
\text { ption }\end{array}$ & $\begin{array}{c}\mathrm{CO}_{2} \\
\text { Emissio } \\
\mathrm{ns} \\
\left(\mathrm{kg} / \mathrm{m}^{2}\right)\end{array}$ \\
\hline Steel $(\mathrm{kg})$ & 53.18 & 47.58 & 64.51 & 57.72 & 72.6 & 64.96 & 56.64 & 22.43 \\
Cement $\left(\mathrm{m}^{3}\right)$ & 0.36 & 97.08 & 0.43 & 116.92 & 0.58 & 157.52 & 119.89 & 47.48 \\
Plaster $(\mathrm{kg})$ & 65.55 & 44.95 & 54.36 & 37.28 & 39.49 & 27.08 & 37.19 & 14.73 \\
Brick $\left(\mathrm{m}^{3}\right)$ & 0.462 & 15.54 & 0.437 & 14.69 & 0.214 & 7.19 & 13.45 & 5.33 \\
Template $\left(\mathrm{m}^{2}\right)$ & 0.85 & 0.29 & 1.03 & 0.35 & 1.35 & 0.46 & 0.36 & 0.14 \\
Window $\left(\mathrm{m}^{2}\right)$ & 0.3 & 8.21 & 0.34 & 9.73 & 0.45 & 19.08 & 11.16 & 4.42 \\
Insulation $\left(\mathrm{m}^{3}\right)$ & 0.01 & 2.28 & 0.01 & 2.56 & 0.02 & 4.21 & 2.81 & 1.11 \\
Others & - & 9.57 & - & 10.85 & - & 13.46 & 11.04 & 4.37 \\
Total $\left(\mathrm{kg}-\mathrm{CO}_{2}\right)$ & - & 225.5 & - & 250.1 & - & 293.96 & 252.54 & 100 \\
\hline
\end{tabular}

3.3.2 Analysis of the percentages of $\mathrm{CO}_{2}$ emissions of major construction materials 


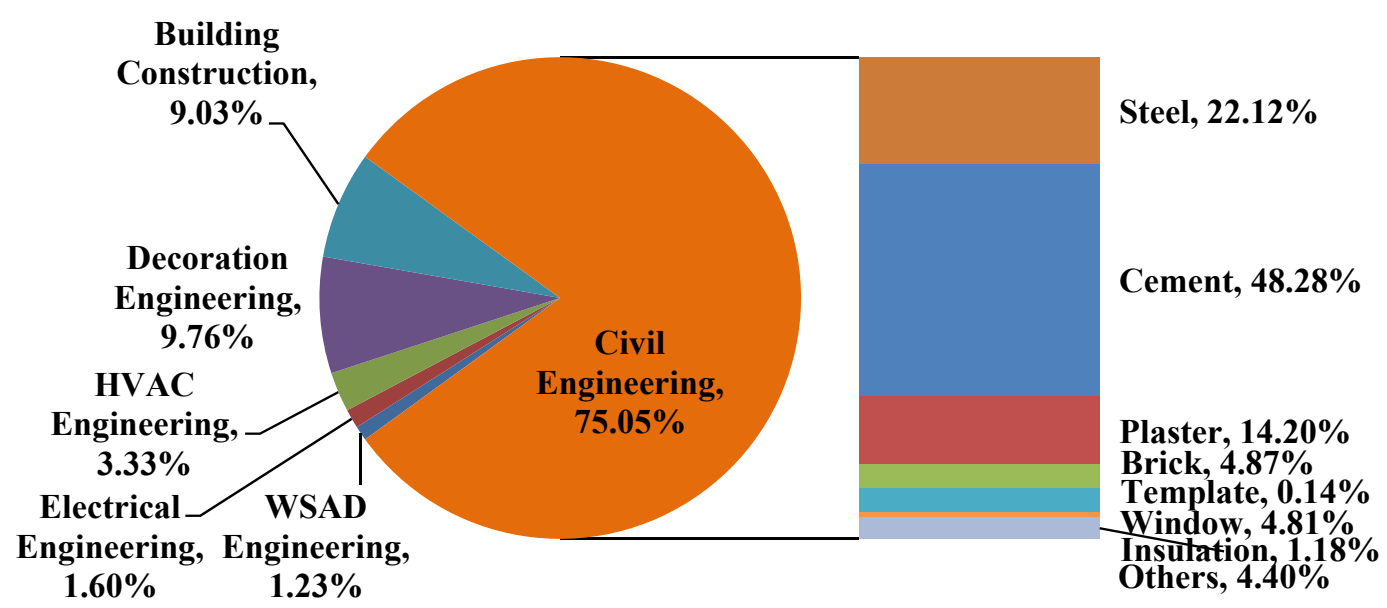

Fig. 1 the proportion pie charts of $\mathrm{CO}_{2}$ emissions of each itemized project in building formation stage and of $\mathrm{CO}_{2}$ emissions of major construction materials

Combining the statistical results of Section 2.3.1 and Section 2.2, we can get the proportion pie charts of $\mathrm{CO}_{2}$ emissions of each itemized project in building formation stage and of $\mathrm{CO}_{2}$ emissions of major construction materials, as shown in Fig. 1. It clearly shows what material in the building formation stage generates the largest amount of $\mathrm{CO}_{2}$ emissions.

\subsection{Correlation analysis of $\mathrm{CO} 2$ emissions between building storeys and construction materials}

In order to determine what construction materials have greater correlation with $\mathrm{CO}_{2}$ emissions of Civil Engineering, this research used statistical analysis software SPSS to make a study of correlation. As shown in Table 4, the significant level a is zero between the carbon dioxide emissions of two construction materials and the building storey, and between the carbon dioxide emissions of four construction materials and the building storey, which shows significant correlation; however, the correlation is more significant between the building storey and $\mathrm{CO}_{2}$ emissions generated from steel and concrete, with Pearson correlation coefficient reaching 0.909. Table 4 Correlation analysis of $\mathrm{CO}_{2}$ emissions between building storeys and construction materials

\begin{tabular}{ccccc}
\hline & $\begin{array}{c}\text { Building } \\
\text { storeys }\end{array}$ & $\begin{array}{c}\mathrm{CO}_{2} \text { Emissions of } \\
\text { steel, concrete }\end{array}$ & $\begin{array}{c}\mathrm{CO}_{2} \text { Emissions of } \\
\text { steel, concrete, } \\
\text { plaster, and brick }\end{array}$ \\
\hline Building & Pearson correlation & 1 & $\mathbf{0 . 9 0 9}^{\mathrm{a}}$ & $\mathbf{0 . 8 1 0}^{\text {a }}$ \\
Stories & Sig. (2-tailed) & - & $<0.001$ & $<0.001$
\end{tabular}




\begin{tabular}{ccccc} 
& $\mathrm{N}$ & 78 & 78 & 78 \\
\hline $\mathrm{CO}_{2}$ Emissions & Pearson correlation & $0.909^{\mathrm{a}}$ & 1 & $0.877^{\mathrm{a}}$ \\
of steel, & Sig. (2-tailed) & $<0.001$ & - & $<0.001$ \\
concrete & $\mathrm{N}$ & 78 & 78 & 78 \\
\hline $\mathrm{CO}_{2}$ Emissions & Pearson correlation & $0.810^{\mathrm{a}}$ & $0.877^{\mathrm{a}}$ & 1 \\
of steel, & Sig. (2-tailed) & $<0.001$ & $<0.001$ & - \\
$\begin{array}{c}\text { concrete, } \\
\text { plaster, and }\end{array}$ & $\mathrm{N}$ & 78 & 78 & 78 \\
Brick & & & & \\
\hline
\end{tabular}

${ }^{\mathrm{a}}$ : Correlation is significant at the 0.01 level (2-tailed)

\section{Discussion}

Based on the above analysis, it can be found that there are strong correlation between the $\mathrm{CO}_{2}$ emissions of major construction materials and the building storey. There come two questions: do the $\mathrm{CO}_{2}$ emissions in the construction materialization stage have some relationships with the consumption of major construction materials and the building storey? Can the correlation between them be used to predicate the $\mathrm{CO}_{2}$ emissions in the construction materialization stage?

\subsection{Prediction of $\mathrm{CO}_{2}$ emissions at different storeys}

From Table 2 and Table 3, a trend can be found as follow: with the increase of building height, there are differences in $\mathrm{CO}_{2}$ emissions per unit area of each itemized project in building formation stage. Therefore, this study made an actuarial study of statistical data of the 78 building samples and tested the correlation between building storeys and $\mathrm{CO}_{2}$ emissions per unit area in building formation stage. Because $\mathrm{CO}_{2}$ emissions per unit area of the samples in building formation stage obey normal distribution, only the linear correlation (as shown in Table 5) requires to be tested. From the results of correlation analysis, it can be determined that there is a strong correlation between the two, with the Pearson correlation coefficient reaching 0.883 .

Table 5 Linear correlation between building storey and $\mathrm{CO}_{2}$ emissions per unit area in the materialization stage of office buildings

\begin{tabular}{llcc}
\hline & Building storeys & $\begin{array}{c}\mathrm{CO}_{2} \text { Emissions of } \\
\text { unit area at } \\
\text { materialization } \\
\text { stage }\end{array}$ \\
\hline Building storeys & Pearson correlation & 1 & $0.883^{\text {a }}$
\end{tabular}




\begin{tabular}{cccc} 
& Sig. (2-tailed) & - & $<0.001$ \\
& $\mathrm{~N}$ & 78 & 78 \\
\hline $\mathrm{CO}_{2}$ Emissions of & Pearson correlation & $0.883^{\mathrm{a}}$ & 1 \\
unit area at & Sig. (2-tailed) & $<0.001$ & - \\
$\begin{array}{c}\text { materialization } \\
\text { stage }\end{array}$ & $\mathrm{N}$ & 78 & 78 \\
\hline
\end{tabular}

a: Correlation is significant at the 0.01 level (2-tailed)

After determining the significant correlation between building storey and $\mathrm{CO}_{2}$ emissions per unit area in the materialization stage of office buildings, the actuarial results were plotted as a scatter graph, where a linear regression analysis was made. It can be seen that $\mathrm{CO}_{2}$ emissions per unit area in the materialization stage increase with the rise of building height; office buildings of the same height also see different distributions in $\mathrm{CO}_{2}$ emissions because of individual variability, but the difference is not huge, showing the diversity and representativeness of the samples. By regression analysis, it can be found that deterministic coefficient $\mathrm{R}^{2}$ of regression equation reaches 0.78 , indicating that it is quite credible to use building storey to predicate $\mathrm{CO}_{2}$ emissions in the materialization stage of office buildings.

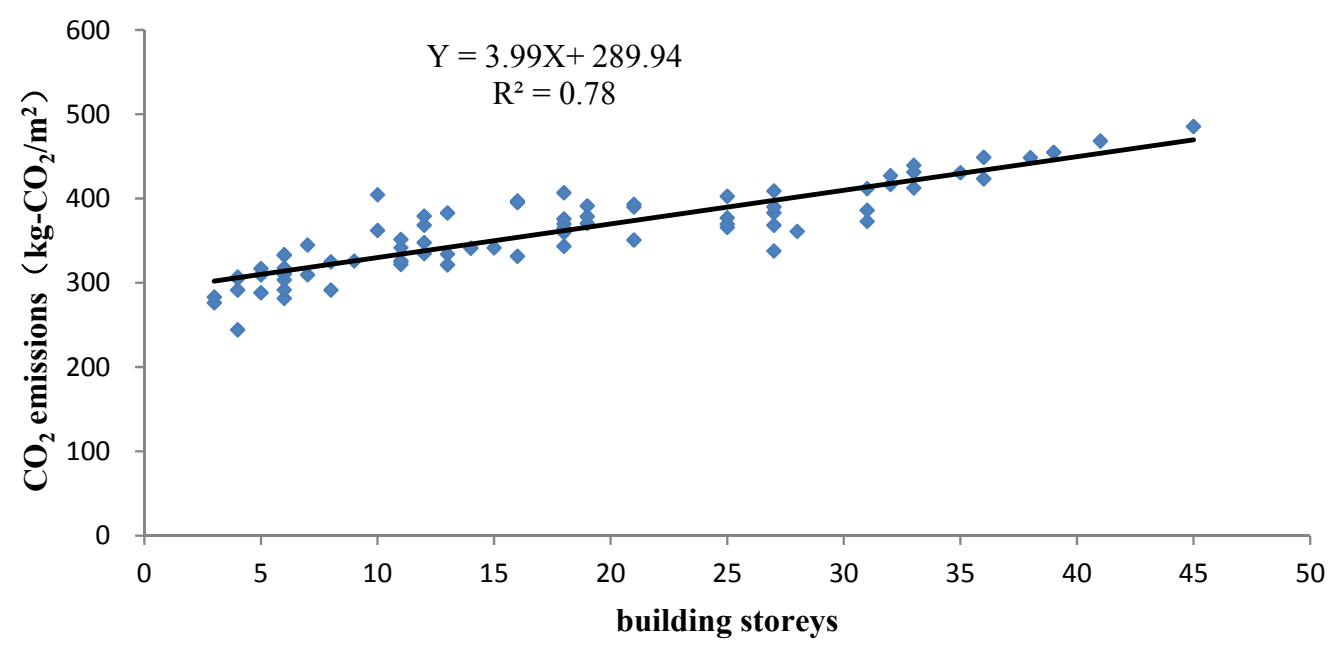

Fig. 2 Scatter distribution and linear regression analysis of $\mathrm{CO}_{2}$ emissions in the materialization stage of office buildings

Considering the slight difference among $\mathrm{CO}_{2}$ emissions of individual cases, we could calculate the mean values of $\mathrm{CO}_{2}$ emissions of buildings at the same storey, reducing the difference degree and making mean values more representative. Hence, the mean values were 
plotted as a scatter graph, where a linear regression analysis was made, as shown in Fig.2. By regression analysis, it could be found that deterministic coefficient $\mathrm{R}^{2}$ of regression equation reaches 0.78 , indicating that the regression equation has a high degree of credibility in prediction.

By above analysis, we can get the predictive equation concerning building storey and $\mathrm{CO}_{2}$ emissions in the materialization stage of office buildings,

$$
\mathrm{LCCO} 2 \mathrm{M}=3.99 \times \mathrm{H}+289.94
$$

where, $\mathrm{H}$ refers to the storey of the building.

\subsection{Prediction of construction material consumption and $\mathrm{CO}_{2}$ emissions}

Construction materials referred to in this section are mainly the four major categories, that is, steel, concrete, mortar and wall materials. The previous analysis has shown that $\mathrm{CO}_{2}$ emissions of Civil Engineering account for over $75 \%$ that of construction materialization stage while $\mathrm{CO}_{2}$ emissions of these four construction materials make up $90 \%$ that of the Civil Engineering. Thus, these four categories are the biggest source of $\mathrm{CO}_{2}$ emissions in materialization stage of office buildings and may have a close relationship with the total $\mathrm{CO}_{2}$ emissions. If the consumption of these four categories can be used for the prediction of $\mathrm{CO}_{2}$ emissions in materialization stage, the complexity of evaluation will be greatly simplified.

At first, we can determine the correlation between these four categories and the total $\mathrm{CO}_{2}$ emissions in materialization stage by dual-variable analysis of the linear correlation, as shown in Table 6. It can be found that the significant levels a are all zero between the total $\mathrm{CO}_{2}$ emissions and the steel, the total $\mathrm{CO}_{2}$ emissions and the concrete, the total $\mathrm{CO}_{2}$ emissions and the wall materials, indicating that the three categories have significant correlation with the total $\mathrm{CO}_{2}$ emissions; the significant levels $\alpha$ is 0.394 between the total $\mathrm{CO}_{2}$ emissions and the mortar, indicating a weak correlation. In terms of Pearson correlation coefficient, the correlation between concrete and the total $\mathrm{CO}_{2}$ emissions is the strongest, while the steel and the wall materials the weakest.

Table 6 Correlation between the four categories of construction materials and the total $\mathrm{CO}_{2}$ emissions in materialization stage

\begin{tabular}{ccccc}
$\mathrm{CO}_{2}$ & Steel & Concrete & Plaster & Brick \\
Emissions & & & \\
\hline
\end{tabular}




\begin{tabular}{ccccccc}
\hline \multirow{2}{*}{$\mathrm{CO}_{2}$} & $\begin{array}{c}\text { Pearson correlation } \\
\text { Emissions }\end{array}$ & 1 & $\mathbf{0 . 5 8 6}^{\mathbf{a}}$ & $\mathbf{0 . 7 0 5} \mathbf{a}^{\mathbf{a}}$ & $\mathbf{0 . 0 9 8}$ & $\mathbf{0 . 3 9 1}$ \\
& Sig. (2-tailed) & & $<0.001$ & $<0.001$ & 0.394 & $<0.001$ \\
& $\mathrm{~N}$ & 78 & 78 & 78 & 78 & 78 \\
\hline \multirow{3}{*}{ Steel } & Pearson correlation & $0.586^{\mathbf{a}}$ & 1 & $0.421^{\mathbf{a}}$ & -0.151 & -0.103 \\
& Sig. (2-tailed) & $<0.001$ & & $<0.001$ & 0.187 & 0.368 \\
& $\mathrm{~N}$ & 78 & 78 & 78 & 78 & 78 \\
\hline \multirow{5}{*}{ Concrete } & Pearson correlation & $0.705^{\mathbf{a}}$ & $0.421^{\mathbf{a}}$ & 1 & $-0.417^{\mathbf{a}}$ & -0.192 \\
& Sig. (2-tailed) & $<0.001$ & $<0.001$ & & $<0.001$ & 0.092 \\
& $\mathrm{~N}$ & 78 & 78 & 78 & 78 & 78 \\
\hline \multirow{5}{*}{ Plaster } & Pearson correlation & 0.098 & -0.151 & $-0.417^{\mathbf{a}}$ & 1 & $0.248^{\mathbf{a}}$ \\
& Sig. (2-tailed) & 0.394 & 0.187 & $<0.001$ & & 0.029 \\
& $\mathrm{~N}$ & 78 & 78 & 78 & 78 & 78 \\
\hline \multirow{2}{*}{ Brick } & Pearson correlation & $0.391^{\mathbf{a}}$ & -0.103 & -0.192 & 0.248 & 1 \\
& Sig. (2-tailed) & $<0.001$ & 0.368 & 0.092 & 0.029 & \\
& $\mathrm{~N}$ & 78 & 78 & 78 & 78 & 78 \\
\hline
\end{tabular}

a: Correlation is significant at the 0.01 level (2-tailed)

After the determination of the significant correlation between the total $\mathrm{CO}_{2}$ emissions and the steel/ concrete/ wall materials, the consumption amounts of these three construction materials could be used as independent variables to predicate the total $\mathrm{CO}_{2}$ emissions in materialization stage. Three groups of predictive variables are tested by statistical software, as shown in Table 7 , and it can be found that when the consumption amounts of the three construction materials are taken as independent variables simultaneously, the adjusted $R^{2}$ reaches a maximum, which illustrates that the explicable variation of the regression equation accounts for the largest proportion of the total variation. The prediction equation is as follow:

$$
\text { LCCO2f }=1.58 \mathrm{X} 1+378.97 \mathrm{X} 2+64.57 \mathrm{X} 3+94.19
$$

where $\mathrm{X}_{1}(\mathrm{~kg})$ is the consumption amount of the steel; $\mathrm{X}_{2}\left(\mathrm{~m}^{3}\right)$ is the consumption amount of the concrete; $\mathrm{X}_{3}\left(\mathrm{~m}^{3}\right)$ is the consumption amount of wall materials.

By variance analysis, this regression equation has a significant probability value of $4.24 \times$ $10^{-36}$, far less than 0.01 , indicating that this regression equation has a considerable degree of practicability. Meanwhile, the $\mathrm{P}$ values of $\mathrm{X}_{1}, \mathrm{X}_{2}$ and $\mathrm{X}_{3}$ are $3.63 \times 10^{-13}, 4.29 \times 10^{-25}$ and $3.21 \times$ $10^{-23} \mathrm{r}$, all far smaller than 0.05 , showing their significant influence on $\mathrm{LCCO}_{2 \mathrm{f}}$.

Table 7 Deterministic coefficient and variance analysis of the three groups of predictive variables

\begin{tabular}{ccccc}
\hline model & $\mathrm{R}$ & $\mathrm{R}^{2}$ & Adjustment of $\mathrm{R}^{2}$ & Std. Error of the Estimate \\
\hline 1 & $0.705^{\mathrm{a}}$ & 0.497 & 0.490 & 35.667 \\
2 & $0.886^{\mathrm{b}}$ & 0.784 & 0.778 & 23.511
\end{tabular}


a. Predictors: (Constant), concrete

b. Predictors: (Constant), concrete, brick

c. Predictors: (Constant), concrete, brick, steel

\subsection{Accuracy analysis of the two predictive methods}

The relevant statistical data of 78 samples were substituted in Formula 6 and Formula 7, and a comparison was made between the calculations results and the actual statistical results, as shown in Fig. 3. It can be found that the predictive results are much closer to the actual statistical results by using Formula 7 than using Formula 6 . And the standard error is $23.36 \mathrm{~kg}-\mathrm{CO}_{2} / \mathrm{m}^{2}$ between the actual results and the predictive results by using building storey, while the standard error is $16.09 \mathrm{~kg}-\mathrm{CO}_{2} / \mathrm{m}^{2}$ between the actual results and the predictive results by using construction materials.

The reason for the above results are that the $\mathrm{CO}_{2}$ emission values predicted by using building storey are the mean values of the statistical data while the $\mathrm{CO}_{2}$ emission values predicted by using construction material are the sample values of the statistical data.

These two prediction models are applied to different stages of architectural design: the prediction model of building storey is applicable to estimate $\mathrm{CO}_{2}$ emissions of office building in planning stage of architectural design, and the prediction model of the three major construction materials is applicable to estimate $\mathrm{CO}_{2}$ emissions of office building in architectural schematic design stage of architectural design. 


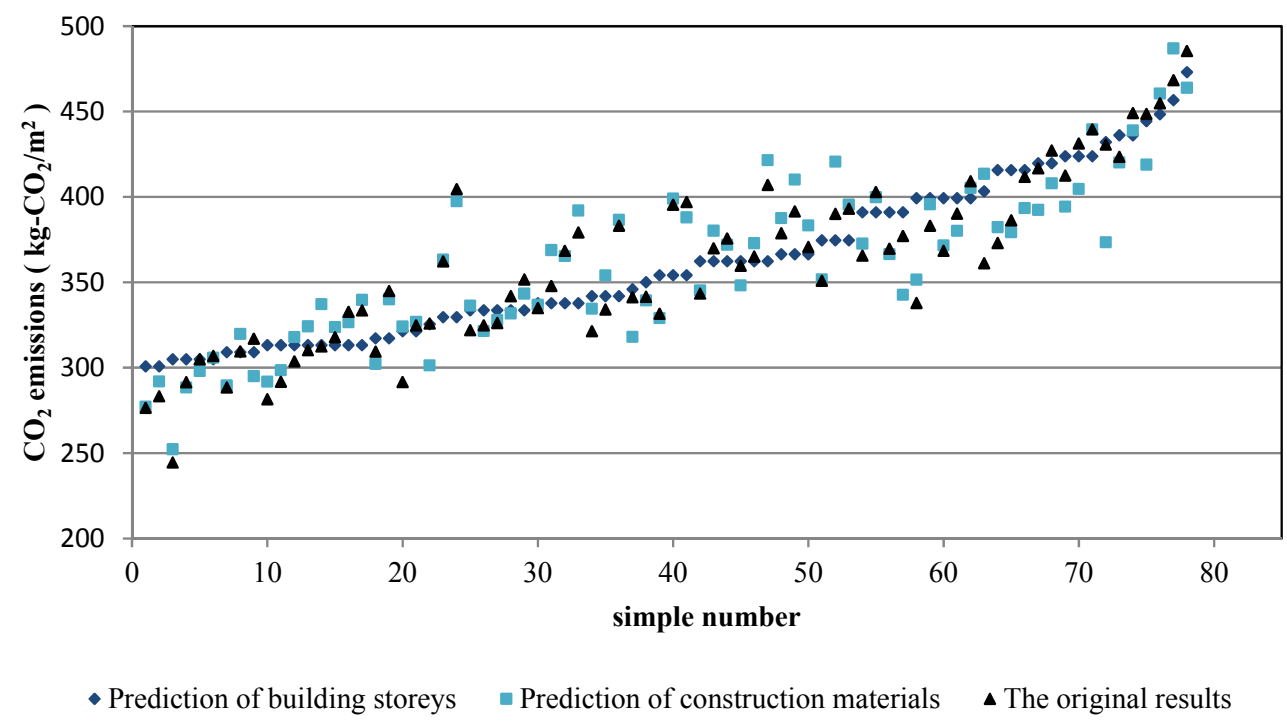

Figure 3 Comparison and analysis of the predictive results and actual results

\section{Conclusion}

$\mathrm{CO}_{2}$ emissions in the materialization stage are the important components of $\mathrm{CO}_{2}$ emissions generated from the life cycle of office buildings, accounting for $5 \%$ 20\% of the latter. Hence, we can analyze the $\mathrm{CO}_{2}$ emissions in the materialization stage of office buildings and come to the following conclusions:

(1) With the increase of building storey (height), $\mathrm{CO}_{2}$ emissions grow significantly in materialization stage of office buildings. The $\mathrm{CO}_{2}$ emission of super high-rise buildings is 1.5 times that of multi-storey buildings, and 1.3 times that of high-rise buildings.

(2) In materialization stage, $\mathrm{CO}_{2}$ emissions of Civil Engineering make up the largest proportion, being 75\%; with the increase of building height, the $\mathrm{CO}_{2}$ emissions of Civil Engineering rise greatly; in terms of installation project and construction project, the $\mathrm{CO}_{2}$ emissions rise more obviously with the increase of building height; the $\mathrm{CO}_{2}$ emissions of installation project has less correlation with the building height.

(3) The $\mathrm{CO}_{2}$ emissions of the four categories of construction materials - steel, concrete, mortar and wall materials make up nearly $90 \%$ of the $\mathrm{CO}_{2}$ emissions of the whole Civil Engineering and the four categories are also the major $\mathrm{CO}_{2}$ emission materials in the materialization stage.

(4) By means of statistics, we can work out the prediction formula concerning building storey and 
$\mathrm{CO}_{2}$ emissions in materialization of office buildings as well as the prediction formulas concerning $\mathrm{CO}_{2}$ emissions in materialization of office buildings and the steel/ concrete/ wall materials. These two kinds of prediction models are suitable for the planning stage and architectural schematic design stage of architectural design.

\section{Acknowledgements}

The research described in this paper was fully supported by the National Science Foundation

for Distinguished Young Scholars of China of China (Grant No. 51325803) and the Innovative Research Team Grant of Shaanxi Province, China (Grant No. 2012KCT-11).

\section{References}

[1] Intergovernmental Panel on Climate Change. Climate change 2014: synthesis report, summary for policymakers.

2014. http://www.ipcc.ch/pdf/assessmentreport/ar5/syr/SYR_AR5_SPMcorr1.pdf.

[2] Yuan JH, Xu Y, Hu Z, et al. China's 2020 clean energy target: Consistency, pathways and policy implications. Energy Policy 2014; 65: 692-700.

[3] Di Placido AM, Pressnail KD, Touchie MF. Exceeding the Ontario Building Code for low-rise residential buildings: Economic and environmental implications. Build Environ 2014; 77: $40-49$.

[4] Wang T, Foliente G, Song X, et al. Implications and future direction of GHGs Emissions mitigation policies in the building sector of China. Renew Sustain Energy Rev 2014; 31: 520 530.

[5] Wan KKW, Li DHW, Liu D, Lam JC. Future trends of building heating and cooling loads and energy consumption in different climates. Build Environ 2011; 46(1): 223e34. 
[6] Wan KKW, Li DHW, Pan W, Lam JC. Impact of climate change on building energy use in different climate zones and mitigation and adaptation implications. Appl Energy 2012; 97: $274-82$.

[7] Li DHW, Pan W, Lam J C. A comparison of global bioclimates in the 20th and 21st centuries and building energy consumption implications. Build Environ, 2014; 75: 236-249.

[8] Wallhagen M, Glaumann M, Malmqvist T. Basic building life cycle calculations to decrease contribution to climate change-Case study on an office building in Sweden. Build Environ 2011; 46(10): 1863-1871.

[9] Roetzel A, Tsangrassoulis A. Impact of climate change on comfort and energy performance in offices. Build Environ 2012; 57:349-61.

[10] Guan L. Energy use, indoor temperature and possible adaptation strategies for air-conditioned office buildings in face of global warming. Build Environ 2012; 55: 8-19.

[11] Singh A, Berghorn G, Joshi S, et al. Review of life-cycle assessment applications in building construction. Journal of Architectural Engineering 2010; 17(1): 15-23.

[12] Suzuki M, Oka T., Estimation of life cycle energy consumption and $\mathrm{CO} 2$ emission of office buildings in Japan. Energy Buildings 1998; 28(1): 33-41.

[13] Cole RJ. Energy and greenhouse gas emissions associated with the construction of alternative structural systems. Build Environ 1999; 34(3): 335-348.

[14] Gerilla GP, Teknomo K, Hokao K. An environmental assessment of wood and steel reinforced concrete housing construction. Build Environ 2007; 42(7): 2778-2784.

[15] Gustavsson L, Joelsson A, Sathre R. Life cycle primary energy use and carbon emission of an eight-storey wood-framed apartment building. Energy Buildings 2010; 42(2): 230-242. 
[16] Kneifel J. Life-cycle carbon and cost analysis of energy efficiency measures in new commercial buildings. Energy Buildings 2010; 42(2): 333-340.

[17] Chen GQ, Chen H, Chen ZM, et al. Low-carbon building assessment and multi-scale inputoutput analysis. Communications in Nonlinear Science and Numerical Simulation 2011; 16(1): 583-595.

[18] Yu D, Tan H, Ruan Y. A future bamboo-structure residential building prototype in China: Life cycle assessment of energy use and carbon emission. Energy Buildings 2011; 43(10): 2638-2646.

[19] Acquaye A, Duffy A, Basu B. Embodied emissions abatement-a policy assessment using stochastic analysis. Energy Policy 2011; 39: 429-41.

[20] Abanda FH, Tah JHM, Cheung FKT. Mathematical modelling of embodied energy, greenhouse gases, waste, time-cost parameters of building projects: a review. Build Environ 2013; 59: 23-37.

[21] Wu P, Xia B, Pienaar J, Zhao X. The past, present and future of carbon labelling for construction materials - A review. Build Environ 2014; 77: 160-168.

[22] Onat NC, Kucukvar M, Tatari O. Scope-based carbon footprint analysis of U.S. residential and commercial buildings: An input-output hybrid life cycle assessment approach. Build Environ 2014; 72: 53-62.

[23] Wan Omar WMS, Doh JH, Panuwatwanich K. Variations in embodied energy and carbon emission intensities of construction materials. Environ Impact Assess Rev 2014;49:31e48.

[24] Thiel CL, Campion N, Landis AE, et al. A materials life cycle assessment of a net-zero Energy Buildings. Energies 2013; 6(2): 1125-1141. 
[25] Zhang X, Shen L, Zhang L. Life cycle assessment of the air Emissions during building construction process: a case study in Hong Kong. Renew Sustain Energy Rev 2013; 17: 160-169.

[26] Dimoudi A, Tompa C. Energy and environmental indicators related to construction of office buildings. Resour Conserve Recycl 2008, 53(1): 86-95.

[27] Luo ZX. Research on evaluation of office buildings' carbon Emissions. Xi'an: Xi'an University of Architecture and Technology, 2011. (in Chinese)

[28] Cuéllar-Franca RM, Azapagic A. Environmental impacts of the UK residential sector: life cycle assessment of houses. Build Environ 2012; 54(8): 86-99.

[29] Hondo H. Life Cycle GHG Emissions Analysis of Power Generation Systems: Japanese Case. Energy 2005; 30(11-12): 2042-2056.

[30] Tae S, Shin S, Woo J, et al. the Development of Apartment House Life Cycle $\mathrm{CO}_{2}$ Simple Assessment System Using Standard Apartment Houses of South Korea. Renew Sustain Energy Rev 2011; 15: 1454-1467

[31] Ge J, Yan Y, Lu J, et al. Chinese Energy/ $/ \mathrm{CO}_{2}$ Intensities Based on 2002 Input-Output Table and Life Cycle Assessment of Residential Building by Accumulative Method. Lowland Technology International 2010; 12(1): 14-22.

[32] Wu X. Research On the Environmental Performance Assessment System of Buildings and its Application. Beijing: Tsinghua University, 2005. (in Chinese)

[33] CHEN HM. Analysis on Embodied $\mathrm{CO}_{2}$ Emissions Including Industrial Process Emissions. China Population Resources and Environment 2009; 19( 3) : 25 30. (in Chinese)

[34] Van den Heede P, De Belie N. Environmental impact and life cycle assessment (LCA) of 
traditional and 'green'concretes: literature review and theoretical calculations. Cement and Concrete Composites 2012; 34(4): 431-442.

[35] Basbagill J, Flager F, Lepech M, et al. Application of life-cycle assessment to early stage building design for reduced embodied environmental impacts. Build Environ 2013; 60:81-92.

[36] Luo ZX, Yang L, Liu JP, et al. Research of $\mathrm{CO}_{2}$ Emissions Calculation Method and $\mathrm{CO}_{2}$ Reduction Strategies of Construction materials. Building Science 2011; 27(4): 1 8. (in Chinese)

[37] Tseng CH. Evaluation of carbon dioxide Emissions of apartment buildings in Taiwan. Taiwan: National Cheng Kung University, 2006. (in Chinese) 